\title{
Effects of glucose on the decolorization of Reactive Black 5 by yeast isolates
}

\author{
YANG Qingxiang ${ }^{1, *}$, TAO Lingxia ${ }^{1,2}$, YANG $\mathrm{Min}^{3}$, ZHANG Hao ${ }^{1}$ \\ 1. College of Life Sciences, Key Laboratory of Environmental Pollution Control Technology of Henan Province, \\ Henan Normal University, Xinxiang 453007, China. E-mail: yangqx66@163.com \\ 2. Biology Department, Puyang Vocational and Technical College, Puyang 457000, China \\ 3. State Key Laboratory of Environmental Aquatic Chemistry, Research Center for Eco-Environmental Sciences, \\ Chinese Academy of Sciences, Beijing 100085, China
}

Received 22 March 2007; revised 21 May 2007; accepted 4 June 2007

\begin{abstract}
The cometabolic roles of glucose were investigated in decolorization of an azo dye, Reactive Black 5, by yeast isolates, Debaryomyces polymorphus and Candida tropicalis. The results indicated that the dye degradation by the tweasts was highly associated with the yeast growth process and glucose presence in the medium. Color removal of $200 \mathrm{mg}$ dye/L was increased from $76.4 \%$ to $92.7 \%$ within $60 \mathrm{~h}$ to $100 \%$ within $18-24 \mathrm{~h}$ with the increase of glucose from 5 to $10 \mathrm{~g} / \mathrm{L}$, although the activity of manganese dependent peroxidase (MnP) decreased by 2-8 times in this case. Hydrogen peroxide of $233.3 \mu \mathrm{g} / \mathrm{L}$ was detected in 6 $\mathrm{h}$ in D. polymorphus culture. The cometabolic functions of glucose and hydrogen peroxide could be also confirmed by the further color removals of $95.8 \%$ or $78.9 \%$ in the second cycle of decolorization tests in which $7 \mathrm{~g}$ glucose/ $\mathrm{L}$ or $250 \mu \mathrm{g} \mathrm{H}_{2} \mathrm{O}_{2} / \mathrm{L}$ was superadded respectively together with $200 \mathrm{mg}$ dye/L.
\end{abstract}

Key words: decolorization; yeast; manganese dependent peroxidase; Azo dye, Reactive Black 5

\section{Introduction}

The serious environmental problems as results of large production and utilization of dyes have been attracted extensive concerns (Wesenberg et al., 2003; Fu and Viraraghavan, 2001). Numerous studies were focused on the biological treatment due to the potentially low cost (Borchert and Judy, 2001). Decolorization of various dyes using white rot fungi or their ligninolytic enzymes was widely studied in the past years and several bioreactors in lab-scale were proposed for this purpose (Borchert and Judy, 2001). However, the rigorous conditions for enzyme production in dye containing wastewater and the risk of contamination by bacteria under non-sterile conditions retard the application of white rot fungi for wastewater treatment (Borchert and Judy, 2001). On the other hand, yeast, another kind of fungi, has been successfully applied to treat industrial effluents such as food-, molasses-, and oil manufacturing wastewater as reported by Japanese scientists (Chigusa et al., 1996; Moriya et al., 1990; Yoshizawa et al., 1981) Although several yeasts were reported to be able to remove dyes through the mechanism of biosorption (Kakuta et al., 1992; Martins et al., 1999; Meehan et al., 2000), reports on decolorization by yeast through the above ligninolytic system have been minimal (Hofrichter, 2002). In our previous reports, two yeast isolates, Debaryomyces polymorphus and Candida tropicalis,

\footnotetext{
*Corresponding author. E-mail: yangqx66@163.com.
}

which could produce manganese dependant peroxidase $(\mathrm{MnP})$ under simple medium conditions and decolorize six different kinds of dyes showed great potentials in colored wastewater treatment (Yang et al., 2003). In the following studies, the optimal conditions for decolorization and MnP production were investigated in detail. The results indicated that the two yeasts could not use dye as a sole carbon or energy source for growth and decolorization. Growth and color removal processes by these two strains were strongly associated with glucose existence in the medium (Yang et al., 2005).

In this study, the evidences of glucose as a cometabolic substrate for decolorization by these two yeasts were provided and the possible mechanisms about enzymatic biodegradation of C. I. Reactive Black 5 (RB5), a widely used azo dye, were discussed.

\section{Materials and methods}

\subsection{Dye}

C.I. Reactive Black 5 (RB5, Color Index) was obtained from Dystar (Germany) as dye formulation Remazol Schwarz B, containing RB5 in $75 \%$ purity. The dye solution was prepared as reported previously (Yang et al., 2003).

\subsection{Microorganisms and decolorization tests}

Debaryomyces polymorphus (Y1-0813) and Candida 
tropicalis (Y2-0814) were isolated from a municipal wastewater treatment plant in Munich City, Germany and preserved in China General Microbiological Culture Collection Center (CGMCC). These two yeasts were cultivated at $28^{\circ} \mathrm{C}, 140 \mathrm{r} / \mathrm{min}$ in the described medium (Yang et al., 2003). Decolorization of RB5 by yeast was detected in $100 \mathrm{ml}$ medium as reported previously (Yang et al., 2005). Glucose concentration was changed from 5 to $10 \mathrm{~g} / \mathrm{L}$.

\subsection{Assay of manganese dependant peroxidase}

MnP was detected using DMAB/MBTH (3-dimethyl amino benzoic acid/3-methyl-2-benzo-thiazlinoe-hydrazone) as described by Lang (Lang et al., 1997). One unit (U) of enzyme activity was defined as the amount of enzyme required producing one micromole of product per minute.

\subsection{Detection of $\mathrm{H}_{2} \mathrm{O}_{2}$ concentration}

$\mathrm{H}_{2} \mathrm{O}_{2}$ concentration in the culture was determined by iodometric titration as described by Harris (1999).

\section{Results and discussion}

\subsection{Correlations between glucose utilization and dye decolorization}

In our previous reports, the decolorization process by $D$. polymorphus was divided into two stages, a rapid degradation stage within the first $16 \mathrm{~h}$ and a slow decolorization stage thereafter. In the first stage, the dye was biodegraded accompanying with the quick growth of yeast and no color

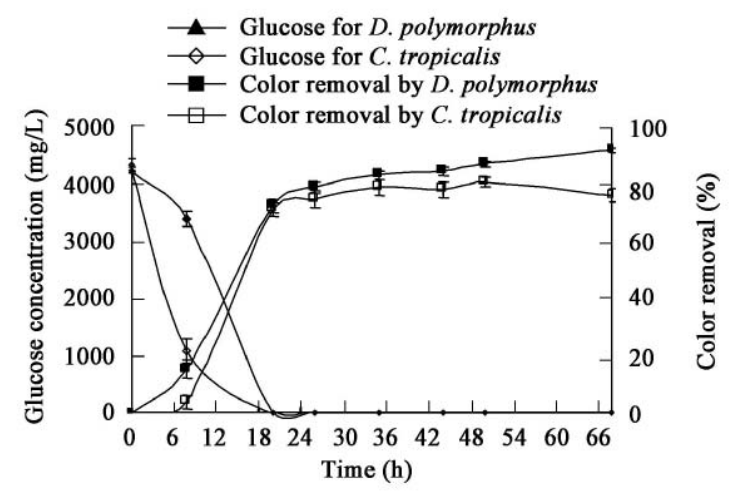

Fig. 1 Kinetic relation between glucose utilization and dye decolorization by D. polymorphus and C. tropicalis (dye conc.: $200 \mathrm{mg} / \mathrm{L}$ ). Each point represents mean $\pm S E$ of triplication.

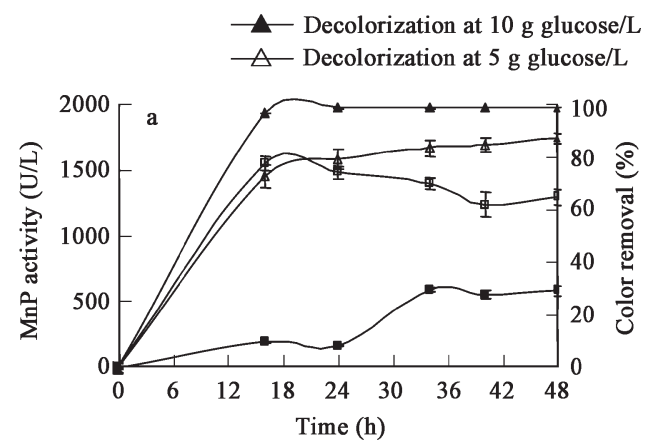

was absorbed on the cells. When the dye could not be removed completely in the fast decolorization stage, the residual color was attached on yeasts giving the cells light pink color (dye concentration of $200-300 \mathrm{mg} / \mathrm{L}$ ) or blue color (dye concentration over $300 \mathrm{mg} / \mathrm{L}$ ) in the following cultivation (Yang et al., 2005). The decolorization process by $C$. tropicalis exhibited the same trend but with lower color removal rates.

In this study, the kinetic process of glucose utilization against cultivation time was detected as shown in Fig.1.

Processes of glucose utilization and dye decolorization by the two yeasts were very similar. Glucose was utilized very fast and exhausted within $20 \mathrm{~h}$ cultivation, which was corresponding to the quick decoloriztion stage of biodegradation. After that, the decolorization process went into a slow stage mainly by biosorption and the final color removal rate for $D$. polymorphus and $C$. tropicalis was only $92.7 \%$ and $76.4 \%$ respectively despite of still high activity of $\mathrm{MnP}$ in the culture as shown in Fig.2. It is obvious that color removal process through mechanism of dye biodegradation by these two yeasts was highly associated with the yeast growth and glucose presence in the medium. In our previous report, the yeasts could not use the dye as a sole carbon and energy source for yeast growth and MnP production (Yang et al., 2005). Glucose acted as a cometabolic substrate for dye degradation, which was similar with the results obtained in white rot fungi by other authors (Adosinda et al., 2001; Swamy and Ramsay, 1999). However, in most white rot fungi, glucose or other carbon sources provided a necessary substrate for cell growth and enzyme production, in which the enzyme production was during their secondary metabolism and was induced by limited nutrient level. The dye degradation process occurred after enzyme production (Wesenberg et al., 2003). In this point, the situation in yeasts was different from most white rot fungi, in which the decolorization process occurred during the exponential growth stage of cells and only under the conditions of enough nutrients existence. The phenomena of decolorization by yeasts suggested another side of glucose functions and an unknown decolorization mechanism.

\subsection{Effects of glucose concentration on MnP production and color removal}

To further confirm the effects of glucose on decoloriza-

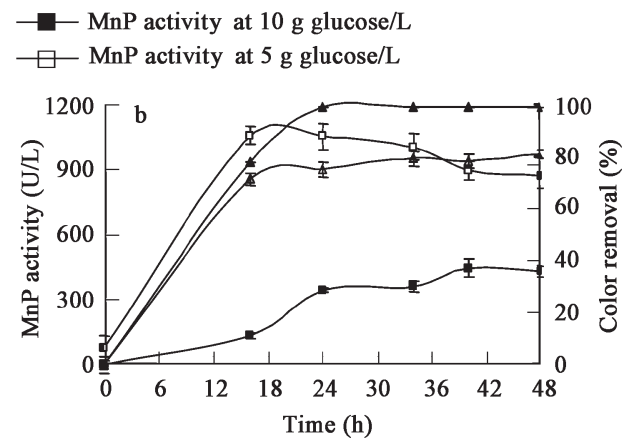

Fig. 2 Comparison of decolorization and MnP activities by yeasts D. polymorphus and C. tropicalis under different concentrations of glucose (dye conc. $200 \mathrm{mg} / \mathrm{L})$. Each point represents mean $\pm \mathrm{SE}$ of triplication. 
tion process, the concentration of glucose was increased to $10 \mathrm{~g} / \mathrm{L}$. Color removals and enzyme activities in these two yeasts were compared under the conditions of 5 and $10 \mathrm{~g}$ glucose/L as shown in Fig.2.

When the glucose concentration was increased to 10 $\mathrm{g} / \mathrm{L}$, complete color removal (100\%) was obtained by D. polymorphus and C. tropicalis within 16 and $24 \mathrm{~h}$, respectively, which was much quicker than that at the condition of $5 \mathrm{~g}$ glucose/L. No slow stage was observed in the decolorization process under higher glucose concentration. However, contrary results were obtained for the relation of $\mathrm{MnP}$ activity and glucose concentration. The $\mathrm{MnP}$ activities at $5 \mathrm{~g}$ glucose/L were about 2-8 times of those at $10 \mathrm{~g}$ glucose/L in these two yeasts. In our previous report (Yang et al., 2005), production of MnP by $D$. polymorphus was induced by the presence of dye. The possible interpretation for the low level of MnP activity at $10 \mathrm{~g}$ glucose/L was that dye degradation was too fast to induce more enzyme production. But it is difficult to elucidate how the yeast cells degrade $200 \mathrm{mg}$ dye/L with so low level of enzyme activity. Besides MnP, there should be other enzymes responsible for color removal of RB5 in the two yeasts.

According to the reports, biodegradation of aromatic hydrocarbon could be catalyzed either by ligninolytic enzyme system including lignin peroxides (LiP), MnP and laccase or by oxygenase in fungi (Cerniglia, 1992). Our previous studies have confirmed that these two yeasts could not produce LiP or laccase (Yang et al., 2003).

Further detection of P450 cytochrome oxygenase indicated that there was no activity of this enzyme in $D$. polymorphus or $C$. tropicalis cells at either presence or absence of dye in the culture. However, low level of P450 oxygenase activity ( 4.07 and $0.8 \mu \mathrm{mol} / \mathrm{g}$ wet cells at presence and absence of dye, respectively) could be detected in another unreported yeast isolate (Rhodotorula mucilaginosa) which could also effectively decolorize RB5, but without activity of ligninolytic peroxidase system. The detail mechanism of decolorization by D. polymorphus and C. tropicalis requires further research. At least, production of $\mathrm{MnP}$ was a kind of response to the presence of dye by these two yeasts and should be related with the process of color removal. As our discussion above, the quick decolorization stage by yeasts was strongly accompanied with the cells growth. It suggested that some unknown enzymes producing in the process of cell growth might be responsible for color removal and glucose might play important roles in this process except as a carbon or energy source for yeast growth. According to Hofrichter, $\mathrm{H}_{2} \mathrm{O}_{2}$ or other peroxide was required to start the reaction when $\mathrm{MnP}$ attacked lignose or phenyl compounds (Hofrichter, 2002). Production of $\mathrm{H}_{2} \mathrm{O}_{2}$ in D. polymorphus culture was monitored over $50 \mathrm{~h}$ under condition of $10 \mathrm{~g}$ glucose/L and $200 \mathrm{mg} \mathrm{RB} 5 / \mathrm{L}$ as in Fig.3. The maximum concentration of $\mathrm{H}_{2} \mathrm{O}_{2}(233.3 \mu \mathrm{g} / \mathrm{L})$ was detected at $6 \mathrm{~h}$ and quickly reduced to an undetectable level at $16 \mathrm{~h}$, which coincided with the trends of glucose exhaustion and dye degradation in Fig.1.

According to the literature (Swanmy and Ramsay, 1999), $\mathrm{H}_{2} \mathrm{O}_{2}$ was normally produced by another enzyme,

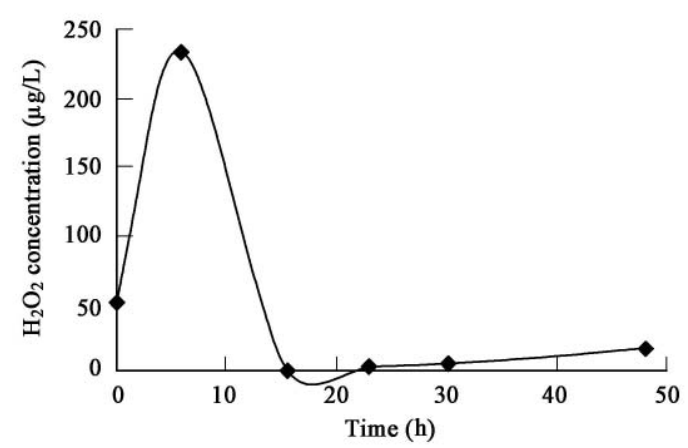

Fig. 3 Production of $\mathrm{H}_{2} \mathrm{O}_{2}$ by $D$. polymorphus over $50 \mathrm{~h}$ under the conditions of $200 \mathrm{mg} \mathrm{RB} 5 / \mathrm{L}$ and $10 \mathrm{~g}$ glucose/L.

glucose peroxidase, which was attached on the cell wall when glucose was used as the main carbon source in the culture (Swamy and Ramsay, 1999). Our results strongly supported Hofrichter's supposing on mechanism of $\mathrm{MnP}$ catalysis and Swamy's view about $\mathrm{H}_{2} \mathrm{O}_{2}$ production (Hofrichter, 2002). In this point, glucose played two important roles in biodegradation of dye: providing a carbon and energy source for yeast growth and acting as a substrate for $\mathrm{H}_{2} \mathrm{O}_{2}$ production.

Further research indicated that $7 \mathrm{~g}$ glucose/L was enough for decolorization of $200 \mathrm{mg}$ RB5/L by $D$. polymorphus as shown in Fig.4. The same result was obtained in C. tropicalis (data not shown here).

\subsection{Effects of superadded glucose and $\mathrm{H}_{2} \mathrm{O}_{2}$ on color removal}

To confirm the cometabolic effects of glucose and $\mathrm{H}_{2} \mathrm{O}_{2}$, three sets of tests were designed in the above flasks containing $7 \mathrm{~g}$ glucose/L and $200 \mathrm{mg}$ RB5/L after the first cycle of decolorization $(22 \mathrm{~h})$. Another dosage of 200 mg RB5/L was superadded into the cultures separately (case 1), together with $7 \mathrm{~g}$ glucose/L (case 2) or together with $250 \mu \mathrm{g} \mathrm{H}_{2} \mathrm{O}_{2} / \mathrm{L}$ (case 3). The results indicated that effective and much quicker color removal was observed only under the condition of cases 2 and $3(95.8 \%$ or $78.9 \%$ at $12 \mathrm{~h}$, respectively). The culture flasks in case 1 did not exhibit obvious color change, which suggested that the decolorization reaction could not be effectively initiated without the presence of glucose or $\mathrm{H}_{2} \mathrm{O}_{2}$ despite of still high $\mathrm{MnP}$ activity and enough amount of biomass

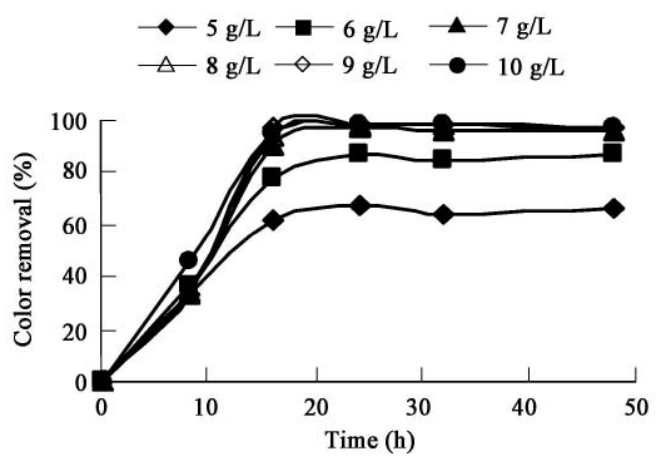

Fig. 4 Effects of glucose concentration on color removal of Reactive Black 5 by D. polymorphus (dye conc., $200 \mathrm{mg} / \mathrm{L}$ ). 
in the culture. The function of $\mathrm{H}_{2} \mathrm{O}_{2}$ in the decolorization processes by the two yeast isolates was obvious although further research was required about the optimal conditions.

A decreased color removal rate of $85.2 \%$ and $74.7 \%$ was obtained respectively in the third and forth cycle of decolorization tests when case 2 was successively repeated every $24 \mathrm{~h}$. Decrease of enzyme activity, inhibition of metabolic products as well as exhaustion of other nutrients might be the reasons for this trend and have already been solved by designing continuous decolorizing bioreactors.

Considering the future application of these two yeasts in real wastewater treatment, other carbon sources such as sucrose, maltose and starch were also tested in batch experiments and only starch could not support the yeasts growth and decolorization (Yang et al., 2005). In our present biofilm reactor inoculated with these two yeasts, municipal wastewater also showed a very effective carbon and nitrogen source for decolorization (The results will be reported in another paper).

\section{Conclusions}

The quick decolorization processes of RB5 through mechanism of biodegradation by yeasts, D. polymorphus and $C$. tropicalis, were highly associated with glucose existence in the medium. For the decolorization of $200 \mathrm{mg}$ dye/L, increase of glucose concentration from 5 to $10 \mathrm{~g} / \mathrm{L}$ obviously increased the color removal efficiency although the production of MnP exhibited reverse trends. Compared with our previous results about the MnP production by $D$. polymorphus, the low activity of enzyme at higher glucose concentration was possibly due to scarce of efficient induction by dye or its intermediate products.

In the process of decolorization, glucose acted as a carbon source for yeast growth and a substrate for $\mathrm{H}_{2} \mathrm{O}_{2}$ production. The latter was considered to start the decolorization and catalytic reaction of $\mathrm{MnP}$. The effective function of glucose and $\mathrm{H}_{2} \mathrm{O}_{2}$ in the second cycle of decolorization tests strongly supported Hofrichter's hypothesis about mechanism of MnP catalysis (Hofrichter, 2002). For complete color removal of $200 \mathrm{mg}$ RB5/L, at least $7 \mathrm{~g}$ glucose $/ \mathrm{L}$ was required by these two yeasts. The detailed mechanism of dye decolorization by these two yeasts and the key enzymes responsible for dye degradation are still required further study.

\section{Acknowledgements}

This work was supported by the Program for New Century Excellent Talents in University in China (No. NCET-05-0612) and the National Natural Science Foundation of China (No. 20677014).

\section{References}

Adosinda M, Martins M, Ferreira I C, Santos I M, Queiroz M J, Lima N, 2001. Biodegrdation of bioaccessible textile azo dyes by Phanerochaete crysoporium. J Biotechbol, 89: 9198.

Borchert M, Judy A L, 2001. Decolorization of reactive dyes by the white rot fungus Trameters versicolor in sequencing batch reactors. Biotechnol Bioeng, 75: 313-321.

Cerniglia C E, 1992. Biodegradation of polycyclic aromatic hydrocarbon: A review. Biodegradation, 3: 351-368.

Chigusa K, Hasegawa T, Yamamoto N, Watanabe Y, 1996. Treatment of wastewater from oil manufacturing plant by yeasts. Wat Sci Tech, 34: 51-58.

$\mathrm{Fu}$ Y, Viraraghavan T, 2001. Fungal decolorization of dye wastewaters: A review. Bioresour Technol, 79: 251-262.

Harris D C, 1999. Quantitative Chemical Analysis (5th ed.), New York: W.H. Freeman and Company, 429.

Hofrichter M, 2002. Review: lignin conversion by manganese peroxidase (MnP). Enzyme Microb Technol, 30: 454-466.

Kakuta T, Tateno Y, Koizumi T, 1992. Azo dye wastewater treatment with immobilised yeast. Hakkokagaku Kaishi, 70: 387-393.

Lang E, Eller G, Zadrazil F, 1997. Lignocellulose decomposition and production of ligninolytic enzymes during interaction of white rot fungi with soil microorganism. Microbial Ecology, 34: 1-10.

Martins M A M, Cardoso M H, Queiroz M J, 1999. Biodegradation of azo dyes by the yeast Candida zeylanoides in batch aerated cultures. Chemosphere, 38: 2455-2460.

Meehan C, Banat I M, McMullan G, 2000. Decolorization of remazol black-B using a thermotolerant yeast, Kluyveromyces marxianus IMB3. Environment International, 26: 75-79.

Moriya K, Iefuji H, Shimoi H, Sato S, Tadenuma M, 1990. Treatment of distillery wastewater discharged from beet molasses-spirits production using yeast. J Ferment Bioeng, 69: 138-140.

Swamy J, Ramsay J A, 1999. Effects of glucose and $\mathrm{NH}_{4}{ }^{+}$concentrations on sequential dye decolorization by Trametes versicolor. Enzyme Microb Technol, 25: 278-284.

Wesenberg D, Kyriakides I, Agathos S N, 2003. White rot fungi and their enzymes for the treatment of industrial dye effluents. Biotechnology Advances, 22: 161-187.

Wesenberg D, Kyriakides I, Agathos W, 2003. White-rot fungi and their enzymes for the treatment of industrial dye effluents. Biotechnol Advances, 22: 161-187.

Yang Q, Yang M, Pritsch K Yediler A, Hagn A, 2003. Decolorization of synthetic dyes and production of manganesedependant peroxidase by new fungal isolates. Biotechnol Lett, 25: 709-713.

Yang Q, Yediler A, Yang M, Kettrup A, 2005. Decolorization of an azo dye, Reactive Black 5 and MnP production by yeast isolate: Debaryomyces polymorphus. Biochem Eng J, 24: 249-253.

Yoshizawa K, 1981. Development of the new treating method of wastewater from food industry using yeast. Nippon Nogeikagaku Kaoshi, 55: 705-711. 